DOI 10.18551/rjoas.2021-11.18

\title{
AGRONOMIC EVALUATION OF THE FOREST AND LAND REHABILITATION IN BANGGO VILLAGE OF MANGGALEWA, DOMPU, INDONESIA
}

\author{
Zulianti, Priyono Joko, Ma'shum Mansur, Wangiyana Wayan* \\ Master's Study Program of Dryland Agriculture, University of Mataram, Lombok, Indonesia \\ *E-mail: w.wangiyana@unram.ac.id
}

\begin{abstract}
Forest and land rehabilitation ("RHL") is an effort to restore, maintain and improve forest and land functions, and to ensure that the implementation is in accordance with the plan, an evaluation is needed. This study aimed to evaluate the success of the forest and land rehabilitation efforts carried out in the RHL Banggo Village, Manggelewa District, Dompu Regency, Indonesia, by focusing activities on evaluating the success of land revegetation efforts using several types of plants (mahogany, candlenut, jackfruit and durian). This study applied an evaluation research method by conducting a direct observation survey in the RHL area located in Banggo Village for 4 months (October 2020 to January 2021). The plant evaluation was carried out based on the Regulation of the Minister of Environment and Forestry No P.105/MENLHK/SETJEN/KUM.1/12/2018. Based on the data collected, in general the forest and land rehabilitation effort in the Banggo location can be categorized as being successful based on the average growth percentage of all rehabilitation plants across evaluation plots $(76.26 \%)$ or across species of the plants $(76.25 \%)$, but one of the plant species, i.e. mahogany showed low growth percentage (57.5\%). However, based on the percentage of plant health, the average across evaluation plots was low (56.22\%). This could be due to the limiting environmental conditions in the Banggo location, which are dominated by clayey soil types with the land physiography is dominated slightly steep to very steep lands with a total area of 138 ha of the total area of 151 ha and low annual rainfall. To improve the success of the forest and land rehabilitation effort in the long-term in the future, better adapted plant species need to be found and tested locally.
\end{abstract}

\section{KEY WORDS}

Agronomic evaluation, agroforestry, land rehabilitation, forest establishment.

Forest and land rehabilitation ("RHL") is an effort to restore, maintain and improve forest and land functions, so that their carrying capacity, productivity, and role in supporting life buffering systems are maintained. Forest and land rehabilitation is carried out on critical land both outside the forest area and within the forest area [1]. Forest and land rehabilitation efforts in West Nusa Tenggara Province continue to be improved every year, but these rehabilitation efforts are still unable to keep up with the rate of increase in the area of deforestation. This creates an imbalance in the rate of deforestation with the rate of rehabilitation which is still high from year to year. The success of forest and land rehabilitation efforts has a major impact on the recovery of deforestation. Based on data from the Environment and Forestry Service, the activities of forest and land rehabilitation were carried out both outside the area and within the forest area through revegetation and reforestation activities from 2016 to 2018 which increased the covering areas, namely 4,077 ha in 2016, 5,368 ha in 2017, and 8,288 ha in 2018, and in 2019 vegetative forest and land rehabilitation in the area carried out by the Watershed Management Center in West Nusa Tenggara Province covering an area of 3,100 hectares spread over Lombok and Sumbawa islands [2].

Forest rehabilitation includes multiple practices that are planned, financed, implemented and monitored by a range of actors. Primary actors generally include governments or their agencies, the corporate sector, private NGOs and smallholders [3]. 
To ensure that the implementation of forest and land rehabilitation is in accordance with the plan, an evaluation is needed, which is aimed at finding out whether the objectives have been achieved or not [4].

The evaluation that has been done is still limited to evaluation of the percentage of plant growth, plant height and percentage of plant health. The success rate of forest and land rehabilitation is very likely to be influenced by land conditions, soil properties, suitability of plant species and socio-economic factors. Therefore, in evaluating forest and land rehabilitation, a more in-depth research method is needed to determine the percentage of plant growth and the factors that influence it. Plant evaluation is intended to determine the percentage of plant growth, plant height and percentage of plant health. Evaluation of land suitability is also intended to determine the suitability of land for the types of plants that have been planted by comparing the characteristics of the prerequisites for plant growth with the existing land conditions. Analysis of soil physical and chemical properties is also needed to determine soil conditions including soil texture, field capacity, permanent wilting point, moisture content, volume weight, specific gravity, $\mathrm{pH}$ and organic $\mathrm{C}$ [5].

This study aimed to evaluate the success of the forest and land rehabilitation efforts carried out in the RHL Banggo Village, Manggelewa District, Dompu Regency, Indonesia, by focusing activities on evaluating the success of land revegetation efforts using several types of plants (mahogany, candlenut, jackfruit and durian), and factors that affect the growth success of these types of perennial plants.

\section{MATERIALS AND METHOD OF RESEARCH}

This research applied an evaluation research method by conducting a direct observation survey in the RHL (forest and land rehabilitation) area located in Banggo Village, Dompu District, Dompu Regency, NTB, Indonesia, which survey was carried out for 4 months, from October 2020 to January 2021.

The research materials used include plant stands, resulted from the activities of forest and land rehabilitation process in 2019 covering an area of 151 ha, and soil samples taken from $\mathrm{RHL}$ locations, while the tools used are maps (1: 10,000 scale) of the forest and land rehabilitation activities in 2019 in the Banggo RHL location, GPS, compass, roll meter, diameter tape, haga-meter, raffia rope, tally sheet, writing instrument, and laboratory test equipment for soil sample analysis.

The plant evaluation was carried out based on the Regulation of the Minister of Environment and Forestry Number P.105/MENLHK/SETJEN/KUM.1/12/2018 concerning the Procedures for the Implementation of Intensive Supporting Activities as well as the Guidance and Control of Forest and Land Rehabilitation Activities using the Systematic Random Sampling method, with Sampling Intensity (IS) of $5 \%$. The measuring plots are made in a rectangle form $(40 \mathrm{~m} \times 25 \mathrm{~m})$, with an area of 0.1 ha, with a distance between plots of $100 \mathrm{~m}$ in the North-South direction and $200 \mathrm{~m}$ in the East-West direction, while the distance between the outermost plots and the plant boundary is set at a minimum of $50 \mathrm{~m}$ and a maximum of $100 \mathrm{~m}$. The evaluation location covering an area of 151 ha was divided into six plots, and in each plot a number of measuring plots of 0.1 ha were made, which were placed by systematic random sampling. The number of measuring plots in each evaluation plot was 12 in plot \#1 (I), 12 in plot \#2 (II), 13 in plot \#3 (III), 13 in plot \#4 (IV), 12 in plot \#5 (V), and 13 in plot \#6 (VI), so that the total of all measuring plots was 75 measuring plots (Figure 1).

Observations and measurement of plant growth were carried out in each measuring plot. Observation variables included plant species, number of plants growing (to calculate the percentage of plant growth), average plant height, plant health (percentage of healthy plants of the number of growing plants), land conditions, understorey plants, types of plant disturbances, and physical and chemical properties of the soil. To analyze the physical and chemical properties of the soil, 2 soil samples were taken per plot. Soil analysis was carried out at the Soil Science Laboratory of the Faculty of Agriculture, University of Mataram. The species of plants observed were candlenut (Aleurites moluccana), mahogany (Swietenia macrophylla), jackfruit (Artocarpus heterophyllus) and durian (Durio zibetinus). The growth 
success of the plants is determined based on the criteria set by the Ministry of Environment and Forestry. A plant species is considered to be successful if the percentage of plant growth is at least $75 \%$ of the number of its seedlings planted in each measuring plot.

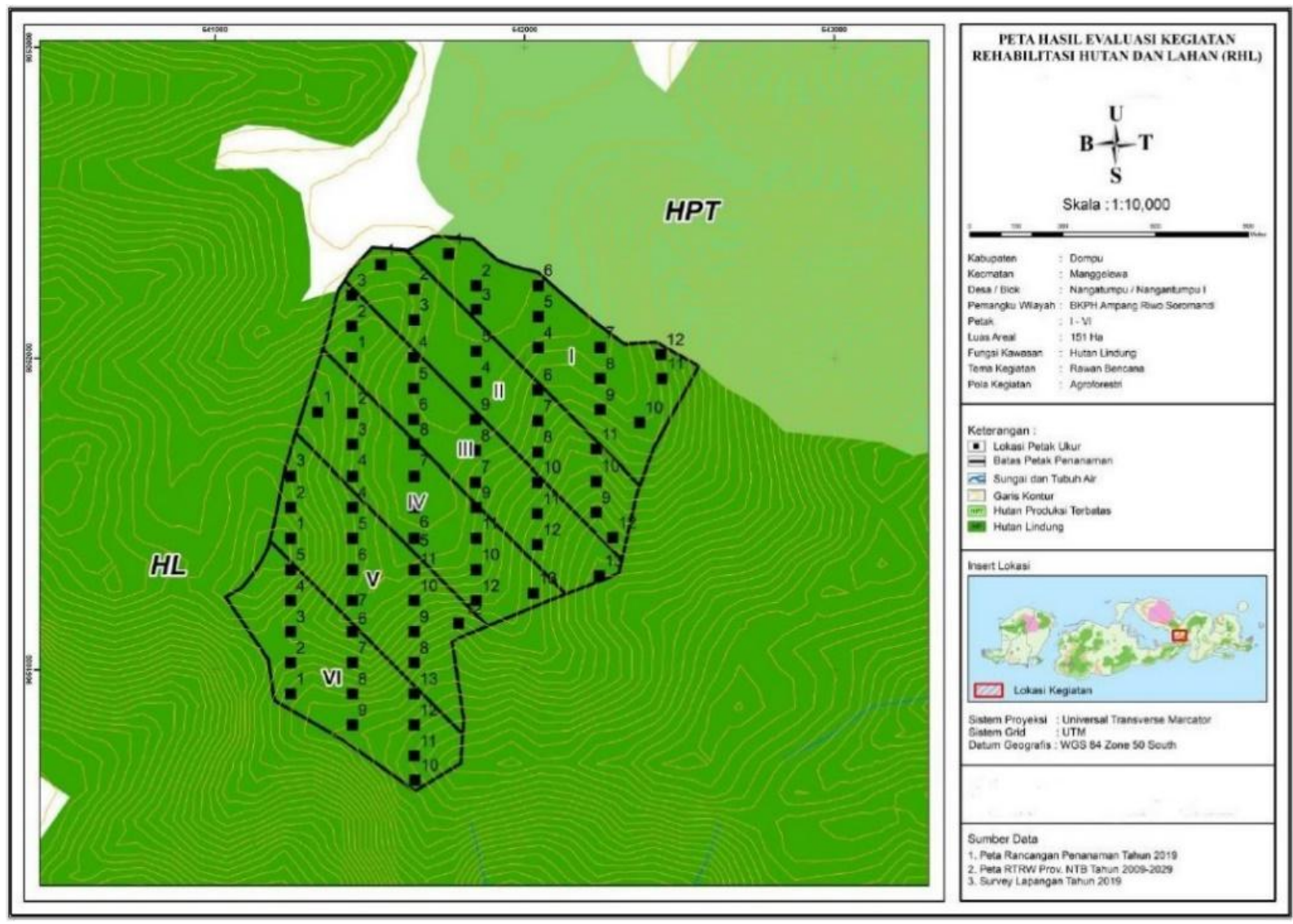

Figure 1 - Spatial position of the six evaluation plots (I, II, III, IV, V and VI) in the Banggo forest and land rehabilitation (scale $=1: 10,000)(\mathrm{HL}=$ protected forest; $\mathrm{HPT}=$ limited production forest)

\section{RESULTS AND DISCUSSION}

The survey location is in the protected forest block of Banggo Nangatumpu \#2. Hydrologically, the location is in the Kambu Watershed (DAS) with geographical coordinates/UTM: $X=640840$ East Longitude $Y=9052572$ South Latitude. The topography of the land based on the overlay of maps of soil types and slopes with a map of the location of the forest and land rehabilitation planting areas in Banggo Village (BKPH Ampangriwo) in 2018 it shows a sloping category (8-15\%) covering an area of 13 hectares, a slightly steep category $(30-45 \%)$ covering an area of 121 hectares and very steep (>45\%) covering an area of 17 hectares. Soil types are Mediterranean Reddish Brown Litosol and Mediterranean Brown Soil. The air temperature in Dompu Regency in 2019 ranged from 20 - $30 \mathrm{C}$, and the average annual rainfall ranged from 1,160-1,400 mm/year [6]. The physiography (slope) of the land at the Banggo location based on field observations at the Banggo $\mathrm{BKPH}$ Ampangriwo location in 2018 shows the flat $(0-8 \%)$, sloping (8-15\%), slightly steep $(16-30 \%)$ steep $(31-45 \%)$ and very steep ( $>45 \%)$, understorey growth condition, soil conditions, and types of disturbance in each study plot are as listed in Table 1.

The results of the evaluation showed that the implementation of forest and land rehabilitation in Banggo Village, Dompu Regency was felt into a successful category, with an average plant growth percentage of $76.25 \%$. The table of the success rate of the living plants was estimated by discrete statistical analysis with a level of $5 \%$ showing the estimated value of the total population of $45,985.33$ plants. The average number of plants was between 298.80 plants/ha and 310.30 plants/ha, while the percentage of plant health was low with an 
average percentage of $56.22 \%$. The detailed recapitulation of the evaluation results is presented in Table 2. However, when growth percentage of each species of the rehabilitation plant was calculated for each species, the result in Table 3 showed that growth percentage of mahogany was very low, i.e. only $57.50 \%$, which is much lower than the minimum value of $75 \%$ as a successful category set by the Indonesian Ministry of Environment and Forestry.

Table 1 - Number of measuring plots in each category of the land conditions

\begin{tabular}{|c|c|c|c|c|c|c|c|c|c|c|c|c|c|c|c|c|c|}
\hline \multirow{2}{*}{ Plot No. } & \multirow{2}{*}{ Total measuring plots } & \multicolumn{5}{|c|}{ Land physiography } & \multicolumn{4}{|c|}{ Understorey growth } & \multicolumn{4}{|c|}{ Soil condition } & \multicolumn{3}{|c|}{ Types of plant disturbance } \\
\hline & & $\overline{F L}$ & $\mathrm{SL}$ & SS & $\mathrm{S}$ & VS & $\mathrm{D}$ & $\mathrm{M}$ & $\mathrm{R}$ & $\mathrm{C}$ & $\mathrm{F}$ & $\mathrm{L}$ & $\mathrm{I}$ & $\mathrm{R}$ & $A G$ & $\mathrm{FF}$ & PD \\
\hline 1 & 12 & 2 & 3 & 3 & 3 & 1 & 2 & 3 & 5 & 2 & 2 & 3 & 5 & 2 & 2 & 3 & 5 \\
\hline 2 & 12 & 2 & 3 & 3 & 2 & 2 & 3 & 3 & 4 & 2 & 3 & 3 & 4 & 2 & 3 & 3 & 4 \\
\hline 3 & 13 & 2 & 2 & 4 & 3 & 2 & 3 & 3 & 3 & 4 & 3 & 3 & 3 & 4 & 3 & 3 & 3 \\
\hline 4 & 13 & 2 & 2 & 5 & 2 & 2 & 2 & 2 & 7 & 2 & 2 & 2 & 7 & 2 & 2 & 2 & 7 \\
\hline 5 & 12 & 3 & 2 & 3 & 2 & 2 & 1 & 3 & 4 & 4 & 1 & 3 & 4 & 4 & 1 & 3 & 4 \\
\hline 6 & 13 & 2 & 3 & 4 & 2 & 2 & 3 & 2 & 6 & 2 & 3 & 2 & 6 & 2 & 3 & 2 & 6 \\
\hline Total & 75 & 13 & 15 & 22 & 14 & 11 & 14 & 16 & 29 & 16 & 14 & 16 & 29 & 16 & 14 & 16 & 29 \\
\hline
\end{tabular}

Note:

FL : flat $\quad$ VS : very steep $C$ : clean $R$ : rocky

$S L$ : sloping $D$ : dense $F$ : fertile $\quad A G$ : animal grazing

SS : slightly steep $M$ : moderate $L$ : less-fertile FF : forest fires

$S$ : steep $R$ : rare I : infertile PD : pest \& diseases

The data in Table 3 shows that on average the growth percentage for durian (Durio zibetinus) was the highest (90\%) with $10 \%$ mortality, followed by candlenut (Aleurites moluccana) with growth percentage of $80 \%$, which means that the mortality of this plant was $20 \%$. Jackfruit (Artocarpus heterophyllus) was in the third position, with a growth percentage of $78.75 \%$ (plant mortality of $21.25 \%$ ), and among those four species of the rehabilitation plants, mahogany (Swietenia macrophylla) showed the poorest growth percentage of only $57.50 \%$, which means its mortality was $42.5 \%$. However, in conditions of suitable land characteristics this plant should grow $100 \%$.

Table 2 - Results of evaluation of the rehabilitation plants in the Banggo RHL until January 2021

\begin{tabular}{|c|c|c|c|c|c|c|}
\hline \multirow{2}{*}{ Plot no. } & \multicolumn{4}{|c|}{ Average plant number per measurement plot in each health category } & \multirow[b]{2}{*}{ Growth percentage (\%) } & \multirow{2}{*}{ Health percentage (\%) } \\
\hline & Healthy & Less healthy & Poor growth & Total growing plants & & \\
\hline 1 & 26 & 2 & 3 & 31 & 77.50 & 83.87 \\
\hline 2 & 18 & 5 & 7 & 30 & 75.00 & 60.00 \\
\hline 3 & 19 & 9 & 3 & 31 & 77.50 & 61.29 \\
\hline 4 & 11 & 11 & 8 & 30 & 75.00 & 36.67 \\
\hline 5 & 18 & 5 & 7 & 30 & 75.00 & 60.00 \\
\hline 6 & 11 & 12 & 8 & 31 & 77.50 & 35.48 \\
\hline \multicolumn{4}{|c|}{ Average } & & 76.25 & 56.22 \\
\hline
\end{tabular}

Table 3 - Growth and health percentage of each species of the rehabilitation plants per ha in the Banggo RHL until January 2021

\begin{tabular}{|c|c|c|c|c|}
\hline Plant species & Planting plan (plant/ha) & Growing plants (plant/ha) & Growth percentage (\%) & Average plant height (cm) \\
\hline Candlenut & 200 & 160 & 80.00 & 40 \\
\hline Mahogany & 80 & 46 & 57.50 & 36 \\
\hline Jackfruit & 80 & 63 & 78.75 & 35 \\
\hline Durian & 40 & 36 & 90.00 & 40 \\
\hline Total/average & 400 & 305 & 76.25 & 37.75 \\
\hline
\end{tabular}

The results of the analysis of the physical and chemical properties of the soil sample taken from each evaluation plot showed that some of the nutrients and other elements required by plants for growth were not in accordance with the land characteristics required by those rehabilitation plants, thus disrupting growth and health of the plants. The results of the analysis of physical properties (soil texture, permanent wilting point, field capacity, moisture content, bulk density, and particle density) and soil chemistry (pH H2O, C-Organic) are presented in Table 4. 
Based on the results of the analysis of the physical and chemical properties of the soil samples taken from the evaluation plots (Table 4), the soil texture at the Banggo location is dominated by clayey soils. According to Hanafiah [7], clayey soils have micro pores and are not porous so they are categorized as less productive. Clayey soil is less supportive for root development because of its low porosity so that it interferes with root respiration in the wet seasons and cracks in the dry seasons, making it difficult for roots to grow well. According to Syamsudin [8], the most ideal soil texture for agricultural land is to have a balanced composition between coarse and fine fractions. With organic matter content of $1.27-2.54 \%$ organic $\mathrm{C}$, based on the criteria of soil organic matter content, the soil in the evaluation plots falls into low to medium category. According to Husni et al. [5], the condition of C-organic indirectly indicates the production of organic matter at the research site. The bulk density of the soil ranged from $1.13 \mathrm{~g} / \mathrm{cm}^{3}$ to $1.19 \mathrm{~g} / \mathrm{cm}^{3}$ and the particle density ranged from $2.17 \mathrm{~g} / \mathrm{m}^{3}$ to $2.22 \mathrm{~g} / \mathrm{m}^{3}$ indicates that the soil at the Banggo location is neither mineral soil nor organic matter soil type, because the particle density of mineral soil particles generally ranges from $2.6 \mathrm{~g} / \mathrm{m}^{3}$ to $2.7 \mathrm{~g} / \mathrm{m}^{3}$ and the particle density of organic soil ranges from $1,3 \mathrm{~g} / \mathrm{m}^{3}$ to $1.5 \mathrm{~g} / \mathrm{m}^{3}$ [9].

Table 4 - Average physical and chemical properties of the soil in each plot

\begin{tabular}{|c|c|c|c|c|c|c|c|c|c|c|c|}
\hline \multirow{2}{*}{$\begin{array}{l}\text { Plot } \\
\text { No. }\end{array}$} & \multirow{2}{*}{$\begin{array}{l}\text { Sam- } \\
\text { ple }\end{array}$} & \multirow{2}{*}{$\begin{array}{l}\text { Soil } \\
\mathrm{pH}\end{array}$} & \multirow{2}{*}{$\begin{array}{l}\text { C-org } \\
(\%)\end{array}$} & \multicolumn{3}{|c|}{ Texture fraction (\%) } & \multirow{2}{*}{$\begin{array}{c}\text { Field } \\
\text { capacity, \% }\end{array}$} & \multirow{2}{*}{$\begin{array}{l}\text { Permanent wilting } \\
\text { point }(\%)\end{array}$} & \multirow{2}{*}{$\begin{array}{c}\text { Moisture } \\
\text { content (\%) }\end{array}$} & \multirow{2}{*}{$\begin{array}{l}\text { Bulk density } \\
(\mathrm{g} / \mathrm{cm} 3)\end{array}$} & \multirow{2}{*}{$\begin{array}{l}\text { Particle } \\
\text { density }\end{array}$} \\
\hline & & & & Clay & Silt & Sand & & & & & \\
\hline \multirow[t]{2}{*}{1} & 1 & 6.7 & 1.27 & 33.80 & 32.87 & 33.33 & 39.10 & 14.52 & 8.74 & 1.14 & 2.18 \\
\hline & 2 & 6.8 & 1.23 & 31.20 & 32.80 & 36.00 & 39.09 & 14.30 & 8.72 & 1.13 & 2.17 \\
\hline \multirow[t]{2}{*}{2} & 1 & 6.6 & 1.33 & 18.20 & 35.13 & 46.67 & 37.23 & 13.99 & 6.98 & 1.16 & 2.19 \\
\hline & 2 & 6.7 & 1.33 & 15.60 & 32.40 & 52.00 & 37.20 & 13.97 & 7.07 & 1.17 & 2.18 \\
\hline \multirow[t]{2}{*}{3} & 1 & 6.8 & 2.15 & 15.60 & 45.73 & 38.67 & 37.19 & 14.51 & 7.70 & 1.16 & 2.19 \\
\hline & 2 & 6.8 & 2.25 & 18.20 & 43.13 & 38.67 & 37.14 & 14.34 & 7.73 & 1.16 & 2.19 \\
\hline \multirow[t]{2}{*}{4} & 1 & 6.5 & 1.74 & 7.80 & 34.87 & 57.33 & 35.52 & 15.09 & 8.65 & 1.17 & 2.22 \\
\hline & 2 & 6.6 & 1.70 & 7.80 & 32.20 & 60.00 & 35.46 & 14.92 & 8.89 & 1.18 & 2.20 \\
\hline \multirow[t]{2}{*}{5} & 1 & 6.5 & 1.93 & 15.60 & 40.40 & 44.00 & 37.11 & 12.42 & 8.68 & 1.16 & 2.18 \\
\hline & 2 & 6.6 & 1,92 & 15.60 & 45.73 & 38.67 & 38.12 & 12.59 & 8.44 & 1.15 & 2.17 \\
\hline \multirow[t]{2}{*}{6} & 1 & 6.9 & 2.54 & 7.80 & 32.20 & 60.00 & 35.42 & 13.51 & 8.64 & 1.18 & 2.21 \\
\hline & 2 & 7.0 & 2.60 & 7.80 & 37.53 & 54.67 & 35.39 & 13.60 & 8.53 & 1.19 & 2.21 \\
\hline
\end{tabular}

Rainfall in the Banggo location ranges from 1,160-1,400 mm/year. This is a growth limiting factor for mahogany and candlenut plants. The available water at field capacity in the soil of the Banggo location was $35.46 \%$ to $39.10 \%$, and based on the theory that field capacity conditions below $50 \%$ will result in disruption of plant growth. Plants under water shortages generally have a smaller size than plants that grow normally. Lack of water causes a very significant decrease in yield and even causes plant death [10].

In relation to soil $\mathrm{pH}$, soil of some measuring plots in the Banggo $\mathrm{RHL}$ locations has soil with a slightly acidic $\mathrm{pH}$. According to Wirosoedarmo et al. [11], soil $\mathrm{pH}$ determines whether or not the nutrients are easily absorbed by plants. Low soil pH increases availability of toxic elements such as Aluminum, which always poisons plants and binds phosphorus so that it become unavailable and cannot be absorbed by plants.

The Banggo location is dominated by a rather steep area with the total area of 121 ha. In the sloping areas, especially those situated in the lower parts of the slope, light can be the main limiting factor in the implementation of forest and land rehabilitation. The steepness of the slope has a lot of influence on the quality of the land. According to Wirosoedarmo et al. [11], the characteristics of the slopes are related to the morphological properties of the land, in which the sloping physiography has more stable soil aggregates than those with steep slopes, because in topography with steep slopes erosion often occurs so that the organic matter and nutrients are lost so that the stability of soil aggregates becomes weak. High rainfall on flat to steep slopes causes high erosion, especially during the rainy seasons $[12,13]$.

Those all environmental limitations are most probably the factors limiting the establishment of the rehabilitation plants in the Banggo forest and land rehabilitation location resulting low health percentages of the rehabilitation plants listed in Table 2 . In addition, the preference of the local community for some specific species of rehabilitation plants also 
contributes to the success of plant growth [14]. In order to make the forest and land rehabilitation efforts for the Banggo location more successful and more sustainable in the long-term, better adapted rehabilitation plants need to be found, which are more adaptable to the limiting environmental factors and are more preferred by the local community so they will help the government in making more successful efforts for the forest and land rehabilitation process in the future.

\section{CONCLUSION}

It can be concluded that in general the forest and land rehabilitation effort in the Banggo location cab be categorized as being successful based on the average growth percentage of all rehabilitation plants across evaluation plots $(76.26 \%)$ or across species of the plants $(76.25 \%)$, but one of the plant species, i.e. mahogany showed low growth percentage $(57.5 \%)$. However, based on the percentage of plant health, the average across evaluation plots was low (56.22\%). This could be due to the limiting environmental conditions in the Banggo location, which are dominated by clayey soil types with the land physiography is dominated slightly steep to very steep lands with a total area of 138 ha of the total area of 151 ha and low annual rainfall. To improve the success of the forest and land rehabilitation effort in the long-term in the future, better adapted plant species need to be found and tested locally.

\section{REFERENCES}

1. Kementerian Lingkungan Hidup dan Kehutanan, 2018. SK Nomor: 306/MenLHK/PDASHL/DAS.0/2018 tentang Penetapan Lahan Kritis Nasional Indonesia. Kementerian Lingkungan Hidup dan Kehutanan, Jakarta.

2. Dinas Lingkungan Hidup dan Kehutanan Propinsi Nusa Tenggara Barat, 2020. Data Rehabilitasi Hutan dan Lahan Propinsi NTB.

3. de Jong, W., 2010. Forest rehabilitation and its implication for forest transition theory. Biotropica, 42(1): 3-9.

4. Maksum, M. 2005. Monitoring dan Evaluasi. Bahan Ajar Manajemen Proyek. Fakultas Teknologi Pertanian, Universitas Gadjah Mada. Yogyakarta.

5. Husni, M.R., Sufardi, S. dan Khalil, M., 2016. Evaluasi status kesuburan pada beberapa jenis tanah di Lahan Kering Kabupaten Pidie Provinsi Aceh. Jurnal IImiah Mahasiswa Pertanian, 1(1): 147-154.

6. Badan Meteorologi, Klimatologi dan Geofisika, Lombok Barat NTB. 2020. Informasi Prakiraan Musim Hujan Tahun 2020.

7. Hanafiah, K. A. 2005. Dasar - Dasar Ilmu Tanah. Cetakan pertama. Jakarta: Raja Grafindo Persada.

8. Syamsudin. 2012. Fisika Tanah. Universitas Hasanuddin, Makassar, Sulawesi Selatan.

9. Blake, G.R. 1986. Particle density. In Methods of Soil. Soc. of Agron, Medison, Wi, USA.

10. Song, A.N. dan Banyo, Y., 2011. Konsentrasi klorofil daun sebagai indikator kekurangan air pada tanaman. Jurnal IImiah Sains, 11(2): 166-173.

11. Wirosoedarmo, R., Sutanhaji, A.T., Kurniati, E. dan Wijayanti, R., 2011. Evaluasi kesesuaian lahan untuk tanaman jagung menggunakan metode analisis spasial. Agritech, UGM, 31(1): p.101338.

12. Arsyad, S. 2101. Konservasi Tanah dan Air. Edisi Kedua. IPB University Press, Bogor.

13. Utomo, M., Sudarsono, Rusman, B Sabrina, T. Lumbanraja, J., \& Wawan, 2016. Ilmu Tanah Dasar-dasar dan Pengelolaan. Prenadamedia Group Jakarta.

14. Danarto, S.A., Budiharta, S. and Fauziah, 2019. Tree species preference and rehabilitation perspective by local community: Case study in Bondowoso, East Java, Indonesia. Asian Journal of Forestry, 3(2): 54-63. 